\title{
Morphological Changes in the Pregnant Uterus of the Smooth Hound Dogfish Mustelus schmitti Springer, 1939 (Gatuzo) (Condrichthyes, Triakidae). Microscopic Study and Phylogenetic Reproductive Implications
}

\author{
Cambios Morfológicos en el Útero Gestante del Gatuzo Mustelus schmitti Springer, 1939 \\ (Chondrichthyes, Triakidae). Estudio Histológico e Implicaciones Filogenéticas y Reproductivas
}

"Galíndez, E. J.; *,**Díaz Andrade, M. C.; "Moya, A. C. \& *Estecondo, S.

GALÍNDEZ, E. J.; DÍAZ ANDRADE, M. C.; MOYA, A. C. \& ESTECONDO, S. Morphological changes in the pregnant uterus of the smooth hound dogfish Mustelus schmitti springer, 1939 (Gatuzo) (Condrichthyes, Triakidae). Microscopic study and phylogenetic reproductive implications. Int. J. Morphol., 28(4):1003-1010, 2010.

SUMMARY: Elasmobranchs are important, not only as an economic resource but also for their phylogenetic position. Their slow growth and long reproductive cycles, together with the high fisheries pressure exerted, attempt to the knowledge of all biological parameters of species. In this work we analyze the histology of the pregnant uterus of the gatuzo, a viviparous aplacental shark. The mucosa depicts modifications similar to those of placental species and others proper of histotrophism. Likewise, a network-like muscular layer in the mucosa was described for first time in the genus. The presence of vitelline plates in the gut of at term embryos suggests that the maternal supplies are not enough for the big fetus development. The relationships between maternal support and embryo growth are discussed into the matrotrophic and phylogenetic contexts.

KEY WORDS: Elasmobranchs; Reproduction; Uterus; Viviparity; Mustelus schmitti.

\section{INTRODUCTION}

Multiple issues support the importance of elasmobranch fishes. On one hand they are the most ancient jawed living group, with all the evolutionary implications and, on the other hand, they constitute an important and increasing economic resource for industrial and artisanal fisheries in the word (Miranda \& Vooren, 2003; Dulvy et al., 2004). The capture of chondrichthyes, even just at extinction point in some regions (Baum et al., 2003), makes difficult to carry out the biological studies of sharks, skates and rays and this knowledge is critical to elaborate appropriate policies for management of stocks (Huveneers et al., 2007).

Viviparity seems to be the plesiomorphic mode of reproduction in gnatostomates (Musick \& Ellis, 2005; Long et al., 2009). Even though this reproductive adaptation involves a delayed rhythm of breeding, it also implies the production of individuals almost ready for survival and successfully prevents the egg predation (Musick \& Ellis). All this, entails important morphological and physiological fittings of females to hold, and even to nourish, the developing young. The elasmobranchs, highly related with Placodermii, show different types of viviparity as reproductive models (Wourms, 1981; Haines et al., 2006). Some of this live-bearing species develop a functional placenta (epitheliochorial-like or vitelline placenta) that nourishes the offspring when the vitelline supplies deplete (Otake \& Mizue, 1985, 1986). In some other species the embryos grow only as a result of the yolk supplies in the egg (Henderson \& Casey, 2001). Between these extremes there is a diversity of variations of the viviparous plan (Hamlett, 2005).

* Lab. Histología Animal, Departamento de Biología, Bioquímica y Farmacia, UNS, San Juan 670, 8000, Bahía Blanca, Argentina.

** CONICET.

Trabajo subsidiado por SGCyT - UNS, PGI 24/B140. Se agradece la valiosa colaboración de la Prefectura Bahía Blanca, en la realización de los muestreos. 
The viviparous genus Mustelus includes about 22 species of temperate waters (Carrier et al., 2004; Oddone et al., 2007) and is a good example of this reproductive diversity. Nine species were reported as placental (M. griseus, M. canis, M. mustelus, M. norrisi, M. higmani, M. dorsalis, M. californicus, $M$. henlei and M. fasciatus) and six as aplacental (M. antarcticus, M. palumbes, M. lenticulatus, M. manazo, M. schmitti and M. mento (Vooren, 1992; Storrie et al., 2009). There is no available information for the other species.

M. schmitti, the gatuzo, is sympatric with another three species of the genus in the Argentine Province (Vooren \& Klippel, 2005; Soto, 2001). This shark is the most important elasmobranch for fisheries in Argentina, composing the 9 to $12 \%$ of the total capture from coastal fleets and their populations show signs of declination (Massa \& Lasta, 2000). As a migratory fish, M. schmitti has three known nursery zones in Argentina: "Bahía de San Borombón", "Bahía Blanca-El Rincón" (both of the Buenos Aires Province) and Bahía Engaño (Chubut Province) (Cousseau, 1986; Van der Molen \& Caille, 2001; López Cazorla, 2007).

There is important information about the biology of this species (Menni, 1985; Cousseau \& Perrota, 2000; Chiaramonte \& Pettovello, 2000; Sidders et al., 2005; Oddone et al., 2005, 2007; Pereyra et al., 2008), and some studies about parasitology (Alarcos et al., 2006), hemopoiesis (Galíndez \& Aggio, 1998; 2002), morphology of the digestive tract (Estecondo et al., 1988), contamination (Marcovecchio et al., 2001) and other topics. In spite of these numerous works about gatuzo, there is no available information concerning their reproductive morphophysiology.

The aim of this work is to provide the first microscopic record of the pregnant uterus of $M$. schmitti as an attempt to enrich the biological knowledge of this important economic resource. In the same way, this study tries to get an insight to the phylogenetic implications of maternal supplies in this aplacental matrotrophic species, which belongs to the most problematic Triakidae genus respect to taxonomy and systematic.

\section{MATERIAL AND METHOD}

Pregnant females were caught in the early summer of 2008, by line fishing in the inner area of the Bahía Blanca estuary $\left(38^{\circ} 45^{\prime}-39^{\circ} 45^{\prime} \mathrm{S}\right.$; 61 $\left.31^{\circ} 30^{\prime}-62^{\circ} 30^{\prime} \mathrm{W}\right)$. During each capture, sea depth was no more than $10 \mathrm{~m}$. Animals, were humanely sacrificed by blunt trauma, measured and immediately dissected. The determination of maturity stage was made according to Stehmann (2002). For light microscopy, tissue samples were fixed in the Bouin's fixative or formaldehyde $10 \%$, both of them in seawater, dehydrated through a graded series of alcohol and embedded in paraffin wax. Sections of 5-7 micrometers were stained with hematoxylin-eosin, Masson's trichromic stain, periodic acid Schiff reaction (PAS) and with the alcian blue technique (AB $\mathrm{pH}$ 2.5). Sections were examined and photographed in an Olympus BX 51 microscope with an Olympus Camedia C7070 camera. For scanning electron microscopy small pieces of different sections of the uterus were fixed in $2.5 \%$ glutaraldehyde in $0.05 \mathrm{M}$ sodium cacodylate buffer with $12 \%$ sucrose (Hyder et al., 1983), for $12 \mathrm{hs}$ at $4{ }^{\circ} \mathrm{C}$ and post fixed in osmium tetroxide $1 \%$ in the same buffer for 90 minutes at $4{ }^{\circ} \mathrm{C}$. Samples were washed in the same buffer, dehydrated in graded acetone, dried by critical point, coated with $\mathrm{Au}-$ Pd by the ion-sputtering method and examined in an Evo 40 XVP (Cambridge, England) scanning electron microscope at $6 \mathrm{KeV}$.

\section{RESULTS}

Anatomy of the uterus. The reproductive system of the sexually mature female is composed of one functional ovary (the left one, Fig. 1), one ostium, two anterior oviducts, two oviductal glands and two uterus that independently lead to one common urogenital sinus. In pregnant females, just at term, the uterus extends along the longitudinal axis of the body occupying about the $50 \%$ of the total length. The gravid uterus displaces all organs and enlarges the female body. Each young inside the organ is enclosed in an individual compartment and shrouded in a thin and translucent wrapping. Embryos are located parallel to the maternal spinal cord, with the head orientated to the mother cranial end and u-bended body.

Histology of the uterus. There are three morphologically different zones in the uterus that are clearly distinguished: the isthmus, which delimits the transition between the oviductal gland and the uterine body, the uterus itself and an sphincter-like zone, called the cervix, that connects with the urogenital sinus. The same four layers are present all over the organ: mucosa, submucosa, muscular and serosa.

Isthmus: The isthmus is a folded short section with a mucosa formed by simple columnar epithelium, with two cell types. One of them, the less abundant, is ciliated with an elongated euchromatic nucleus located in the medium third of cell. The other one is a large mucous cell with a basal and 

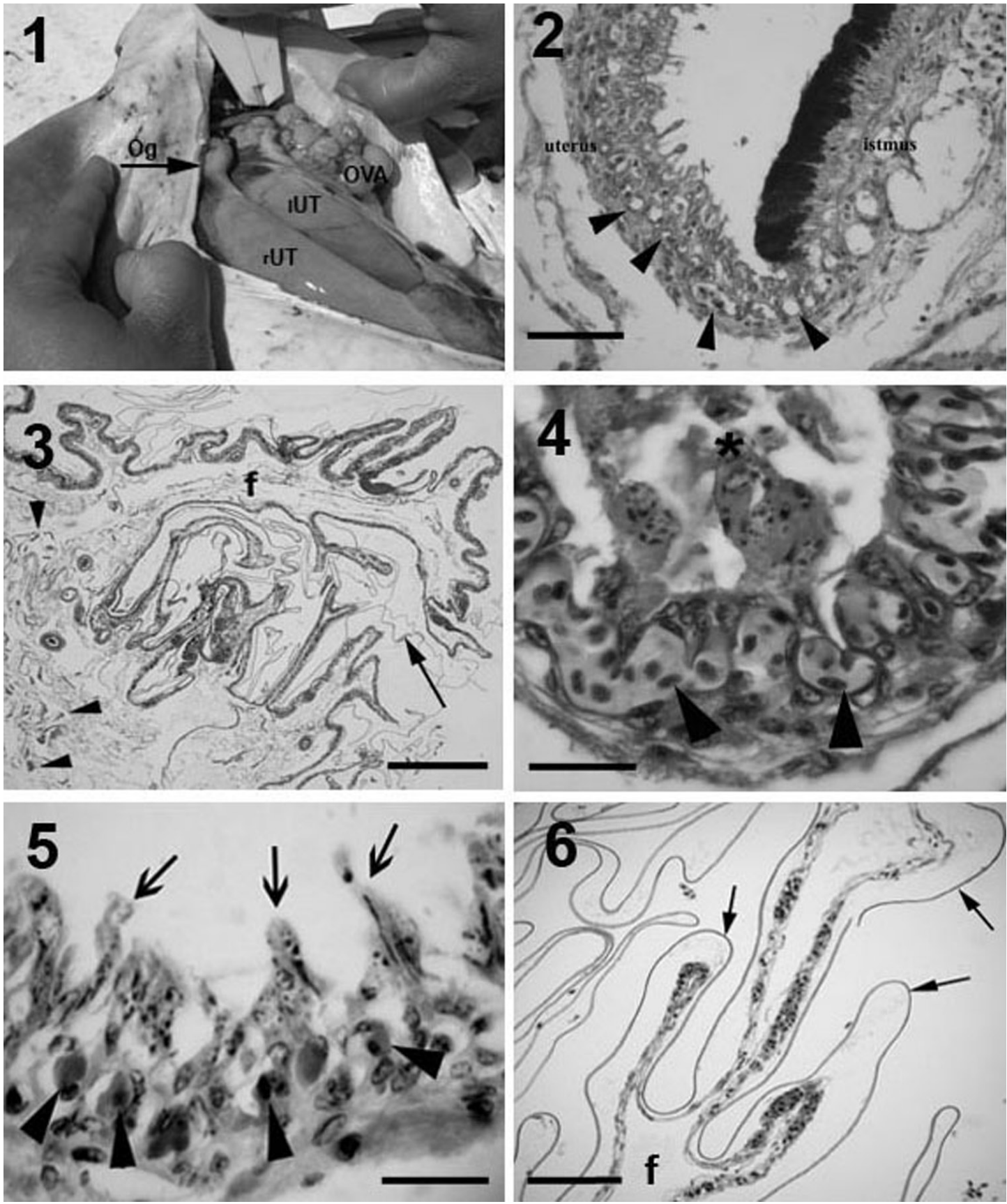

Fig. 1. General view of reproductive organs in a pregnant female. Ova: ovarium; lUt: left uterus; rUt: right uterus; Og: oviductal gland.

Fig. 2. Transition between the body of the uterus and the isthmus. Look at the strong PAS positive reactivity of isthmus epithelium. Arrowhead indicates the vascular net underlying the epithelium. PAS reaction. Scale bar $=1200 \mu \mathrm{m}$.

Fig. 3. General view of the uterine folded mucosa. f: fold; arrow: egg envelope; arrowheads indicate the muscularis mucosae. Masson trichromic. Scale bar $=200 \mu \mathrm{m}$.

Fig. 4. High magnification of the basal stratified epithelium. The PAS reaction allows view of the general reactivity of cells and the delineating of the capillaries (arrowhead). Asterisk depicts cell desquamation. PAS reaction.v Scale bar $=$ $20 \mu \mathrm{m}$.

Fig. 5. High magnification of the basal stratified epithelium. Arrows indicate apoptosis of apical cells and arrowheads mark the capillary network. Masson trichromic. Scale bar $=20 \mu \mathrm{m}$.

Fig. 6. Low magnification of epithelial folds (f) interdigitated with the egg envelope (arrows). Masson trichromic. Scale bar $=50 \mu \mathrm{m}$. 

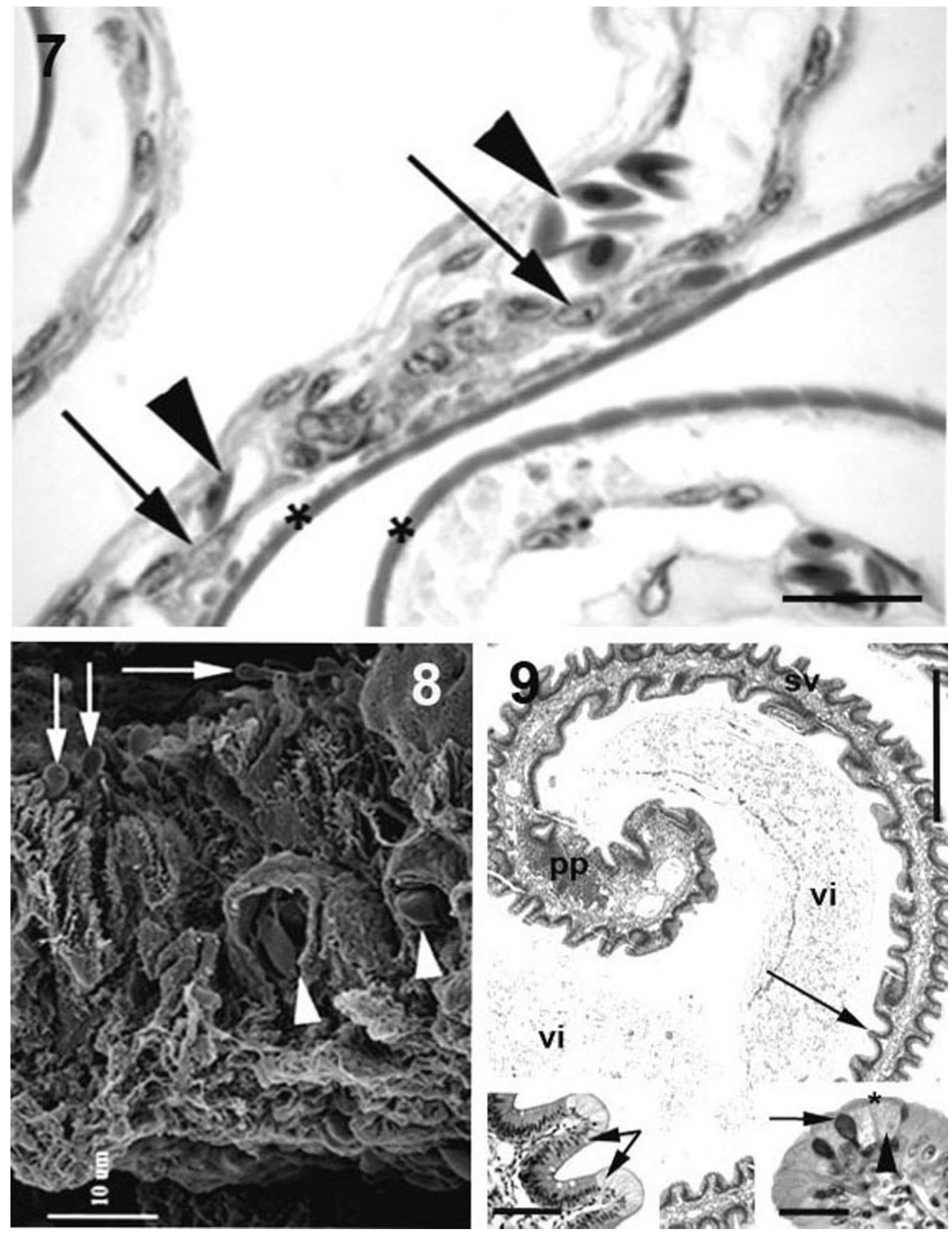

Fig. 7. High magnification of the distal epithelium of folds. Look at the egg envelope (asterisks) that is closely apposed to the simple epithelium (arrows). Arrowheads indicate vascularization. Notice that interspersed between epithelium and envelope there is an amorphous material. At the superior right angle it is possible to see another fold with a considerable space between the epithelium and the envelope. Scale bar $=30 \mu \mathrm{m}$.

Fig. 8. SEM image of a distal fold. Arrowheads depict vascularization meanwhile arrows show secretory vesicles. Scale bar = $10 \mu \mathrm{m}$.

Fig. 9. Low magnification of the spiral valve of the embryo. Right low insert depicts caliciform cell (arrow) and asterisk points the brush border of absorptive cells. Left low insert shows the intestinal villi with the absorptive cell in the villi's apex (arrows). vi: yolk (vitellus); pp: Peyer's patch; sv: spiral valve. Scale bar $=800 \mu \mathrm{m}$, left low insert $=30 \mu \mathrm{m}$, right low insert $=20 \mu \mathrm{m}$. 
more rounded nucleus. All these glandular cells are PAS positive (Fig. 2), but only some are $\mathrm{AB}, \mathrm{pH} 2.5$ positive for both type. The lamina propria and the submucosa show no particular features and are composed of a soft vascularized connective tissue. The muscular comprises two orthogonal layers of smooth muscle, with the inner in a circular disposition. Finally, the serosa delimits the organ being a fine layer of dense connective tissue and a simple squamous to cuboidal epithelium.

Uterine body: When females mature and even in an "adolescent stage", all the reproductive organs modify. In animals classified at stage II of maturity (with small translucent or opalescent ova without macroscopic signs of vitellogenesis), both uterus begin to expand from the distal end so, that previous to the copula, they are fully developed.

The principal feature of this zone is the highly folded mucosa with long primary folds that ramifies (Fig. 3). The epithelium lining the basal portion of the folds is stratified cuboidal. The distal part of primary folds and secondary ones is covered by a single epithelium. Underlining the uterine surface there is a highly developed vascular net, including capillaries and small arteries. The connective lamina propria includes blood and lymphatic vessels, autonomic ganglions and an extremely developed plexiform net of smooth muscle cells that conform, because of their position, a muscularis mисоsae (Fig. 3). This muscular framework is evident from the beginning of enlargement of the uterus and reaches its maximal distension in the term gravid organ. The remaining tunics are a lightly dense and vascularized submucosa, a trilayered muscular stratum disposed internally circular and media and externally longitudinal, both latter separated by a fine sheet of connective tissue, and one typical serosa.

In the mucosa, the cells of the apical layer of the basal stratified epithelium have their apical cytoplasm plenty of acidophilic granules. All cells show evidence of mucous secretion (Fig. 4), even though some depict explicit signs of apoptosis and desquamation (Fig 5). Likewise, they show cytoplasmic PAS and AB 2.5 positive granules. The secondary folds are frequently interdigitated with the egg case that envelops the embryo (Fig. 6). In some instances there is a narrow apposition between them and, in others, a small space is interspersed (Fig. 7). All the folds are extremely thin at the distal end, with a single squamous epithelium, a vestigial connective lamina propria, with numerous juxtaposed capillaries and a simple serosa. The cells of these epithelial folds show PAS and AB 2.5 positives granules. Evidence of secretion is shown in Fig. 8.

In the anterior end of each chamber there is a reservoir of egg case.
Cervix: The last portion of the uterus, the cervix, shows a cuboidal stratified epithelium and a well developed orthogonal muscular layer. The submucosa and the serosa are typical.

Embryos. All the examined embryos were at term and measured between 25 to $27.5 \mathrm{~cm}$ of total length. No evidence of internal yolk sac or vitelline stalk was seen. The embryos gut was distended and showed the typical spiral valve. A high proportion of the intestinal lumen was occupied by vitelline platelets. The intestinal epithelium was simple columnar with brush border and caliciform cells interspersed between absorptive cells. In the apex of villi the absorptive cells were large and their cytoplasm seemed hollowed. Some of these cells showed small PAS positive granules and other ones depicted medium granules, similar in coloration to vitelline platelets (Fig. 9), that mostly occupied the apical cytoplasm, beneath the plasma membrane.

\section{DISCUSSION}

The gatuzo is a small shark species inhabiting from Southern Brazil $\left(22^{\circ} \mathrm{S}\right)$ to Patagonia $\left(47^{\circ} \mathrm{S}\right)$, at less than $140 \mathrm{~m}$ depth (Figueiredo, 1977; Cousseau \& Perrota). It is an annual aplacental species, with parturition in the area in spring or early summer and a mean litter value of 4 (1 to 13) (López Cazorla). It is an important economic resource that comprises an increasing proportion of the elasmobranchs disembarked in Argentine harbors. Actually, there are clear evidences of an intense fishing pressure, as indicated by the decrees of biomass in the platform and by a reduction in the $\mathrm{LT}_{50 \%}$ (Cortés \& Massa, 2006).

The anatomy of the reproductive system of $M$. schmitti agrees, in general, with other selachians species studied (McMillan, 2007), but a bigger difference is that the functional ovary is the left one, when the most common feature in the genus is the inverse.

The mucous nature of the isthmus's epithelium has been shown in other Triakidae as M. antarcticus (aplacental) and Iago omanensis (placental) (Fishelson \& Baranes, 1998; Storrie et al.). This fact, coupled with the presence of abundant cilia, may indicate a role in the lubrication and translocation of the coated zygote from the oviductal gland to the uterus.

The general micro architecture of the organ body ressembles other selachian uterus with the same four tunicas present (McMillan). Even though the mucosa is the most variable layer displaying adaptations to the pregnancy, the presence of a muscular net in the inner coat, not reported 
before in other studied species, depicts a new morphological reproductive accommodation in the genus. It is likely, that the presence of this muscular system may be essential to enable the high expansion of the uterus wall and its return to the initial point, especially if we take into account the small size of females (until $95 \mathrm{~cm}$, Cortés \& Massa) and the large size of litters (1-13 embryos measuring, in average $26 \mathrm{~cm}$ of total length Cousseau \& Perrota).

The presence of uterine compartments formed by the uterus's wall is typical for placental sharks (McMillan) but not exclusive (Chen \& Mizue 1973; Walker, 2007). In the gatuzo, the absence of internal yolk sac and the occurrence of mucous secretion, as well as the evidence of desquamation and apocrine secretion of epithelial fold cells, agrees with other aplacental elasmobranchs (McMillan).

The thinness of cell layers between the maternal blood vessels and the embryo, that diminishes the diffusion distance, as well as the interdigitations between the egg envelope and uterus, suggest an active participation of these structures in the ionic and fluid homeostasis. On the other hand, the unique information about embryonic growth in $M$. schmitti indicates one increase in the embryos weight from $2 \mathrm{~g}$ (egg) to $39 \mathrm{~g}$ (newborn) (Vooren) and this values suggest some degree of matrotrophism, even if we bear in mind the water contribution. Nevertheless, in this case, the presence of vitelline platelets in the spiral valve of at term embryos may indicate that the maternal support is complementary all through the development of big embryos. Most of these features are shared with $M$. antarcticus and constitute additional evidence for an alternative mode of viviparity in sharks (Storrie et al.) that may be used in the study of the placental viviparity of sharks and their phylogenetic implications.

The knowledge of all biological features and especially reproductive traits of fishes is essential for an adequate policy of fisheries. Likewise, sharks of genus Mustelus have some characteristics that, under an adequate management, may enable a sustainable exploitation (Cortés \& Massa). The new data here exposed may contribute to better knowledge of the species and also for economic exploitation as well as for evolutionary analysis. In this latter case more information about the morpho-physiology of members of the genus is needed to cast light on the origin of placentotrophy in elasmobranchs (López et al., 2006) and this work gives information about a member of this genus that is the most problematic with respect to taxonomy and systematic (López et al.).

\section{ACKNOWLEDGMENT}

We thank the Prefectura Naval Bahía Blanca for their help in samplings. This work was supported by the SGCyTUNS, PGI 24/B140.

GALÍNDEZ, E. J.; DÍAZ ANDRADE, M. C.; MOYA, A. C. \& ESTECONDO, S. Cambios morfológicos en el útero gestante del gatuzo Mustelus schmitti Springer, 1939 (Chondrichthyes, Triakidae). Estudio histológico e implicaciones filogenéticas y reproductivas. Int. J. Morphol., 28(4):1003-1010, 2010.

RESUMEN: Los peces cartilaginosos son importantes tanto desde el punto de vista evolutivo como desde el comercial, ya que integran una parte importante de las pesquerías argentinas. El gatuzo es explotado intensamente, pero se desconocen todos los parámetros biológicos necesarios para establecer medidas adecuadas de manejo sustentable. En este trabajo se estudia la arquitectura del útero gestante de esta especie vivípara aplacentaria. Se observaron cambios estructurales en el epitelio uterino así como secreción mucosa y descamación del mismo. Asimismo se describe una túnica muscular reticuliforme en la mucosa, que no había sido referida para ningún otro elasmobranquio. Se aportan evidencias de un histotrofismo moderado. Se observó la presencia de vitelo en la válvula espiral de los embriones gestantes, lo que junto con la secreción uterina, contribuye al desarrollo de los fetos. Se discute la importancia del aporte materno en el crecimiento embrionario, desde el punto de vista de los diferentes tipos de matrotrofismo.

PALABRAS CLAVE: Elasmobranquios, Reproducción, Útero, Viviparidad, Mustelus schmitti.

\section{REFERENCES}

Alarcos, A.; Ivanov, V. \& Sardella, N. Distribution patterns and interactions of cestodes in the spiral intestine of the narrownose smooth-hound shark, Mustelus schmitti Springer, 1939 (Chondrichthyes, Carcharhiniformes). Acta Parasitol., 51(2):100-6, 2006.
Baum, J.; Myers, R.; Kehler, D.; Worm, B.; Harley, S. \& Doherty, P. Collapse and conservation of shark populations in the Northwest Atlantic. Science, 299(5605):389-92, 2003. 
GALÍNDEZ, E. J.; DÍAZ ANDRADE, M. C.; MOYA, A. C. \& ESTECONDO, S. Morphological changes in the pregnant uterus of the smooth hound dogfish Mustelus schmitti springer, 1939 (Gatuzo) (Condrichthyes, Triakidae). Microscopic study and phylogenetic reproductive implications. Int. J. Morphol., 28(4):1003-1010, 2010.

Carrier, J.; Pratt, H. \& Castro, J. Reproductive biology of elasmobranchs. In: Carrier, J.; Musick J. \& Heithaus, M. (eds.). Biology of sharks and their relatives. Boca Ratón, CRC, 2004.

Chen, C. \& Mizue, K. Studies on sharks-VI. Reproduction of Galeorhinus japonicus. Bull. Fac. Fish. Nagasaki Univ., 36:37-51, 1973.

Chiaramonte, G. \& Petovello, A. The biology of Mustelus schmitti in Southern Patagonia, Argentina. J. Fish Biol., 57(4):930-42, 2000.

Cortés, F. \& Massa, A. Aspectos reproductivos del gatuzo (Mustelus schmitti). Inf. Tco. $N^{\circ}$ : 81. Mar del Plata, INIDEP, 2006.

Cousseau, B. Estudios biológicos sobre peces costeros con datos de dos campañas de investigación realizadas en 1981.VI. El gatuso (Mustelus schmitti). Frente Marítimo, 1(1):60-5, 1986.

Cousseau, B. \& Perrotta, R. Peces marinos de Argentina: Biología, distribución, pesca. Mar del Plata, INIDEP, 2000 .

Dulvy, N.; Ellis, J.; Goodwin, N.; Grant, A; Reynolds, J. \& Jennings, S. Methods of assessing extinction risk in marine fishes. Fish Fish., 5(3):255-76, 2004.

Estecondo, S.; Codón, S. \& Galíndez, E. Estudio anátomohistológico del tracto digestivo de Mustelus schmitti (Chondrichthyes, Triakidae). Physis (Buenos Aires), 46(110):31-41, 1988.

Figueiredo, J. Manual de peixes marinhos do Sudeste do Brasil. Introdução: Caçoes, raias e quimeras. São Paulo, Museu de Zoologia da Universidade de São Paulo, 1977.

Fishelson, L. \& Baranes, A. Observations on the Oman shark, Iago omanensis (Triakidae), with emphasis on the morphological and cytological changes of the oviduct and yolk-sac during gestation. J. Morphol., 236(3):15165,1998 .

Galíndez, E. \& Aggio, M. The spleen of Mustelus schmitti (Chondrichthyes, Triakidae): A light and electron microscopic study. Icthyol. Res., 45(2):179-86, 1998.

Galíndez, E. \& Aggio, M. The granulopoietic organs of the narrow nose smooth-hound Mustelus schmitti (Chondrichthyes, Triakidae). A light and electron microscopic study. Rev. Chil. Anat., 20(1):49-54, 2002.
Haines, A.; Flajnik, M. \& Wourms, J. Histology and immunology of the placenta in the atlantic sharpnose shark, Rhizoprionodon terraenovae. Placenta 27(1112):1114-23, 2006.

Hamlett, W. Reproductive Biology and Phylogeny of Chondrichthyes: Sharks, batoids and chimaeras. Enfield, Science Publishers, 2005.

Henderson, A. \& Casey, A. Reproduction and growth in the lesser-spotted dogfish Scyliorhinus canicula (Elasmobranchii: Scyliorhinidae), from the West coast of Ireland. Cah. Biol. Mar. 42(4):397-405, 2001.

Huveneers, C.; Walker, T.; Otway, N. \& Harcourt, R. Reproductive synchrony of three sympatric species of wobbegong shark (genus Orectolobus) in New SouthWales, Australia: Reproductive parameter estimates necessary for population modeling. Mar. Freshwater Res., 58(8):765-77, 2007.

Hyder, S.; Cayer, M. \& Pettey, C. Cell types in peripheral blood of the nurse shark: an approach to structure and function. Tissue Cell, 15:437-55, 1983.

Long, J.; Trinajstic, K. \& Johanson, Z. Devonian arthrodire embryos and the origin of internal fertilization in vertebrates. Nature, 457(7233):11247, 2009.

López, J.; Ryburn, J.; Fredigo, O. \& Naylor, G. Phylogeny of sharks of the family Triakidae (Carcharhiniformes) and its implications for the evolution of carcharhiniform placental viviparity. Molec. Phylog. Evol., 40:50-60, 2006.

López Cazorla, A. Peces. In: Piccolo, M. C. \& Hoffmeyer, M. (eds). Ecosistema del estuario de Bahía Blanca. $3^{\text {th }}$ ed. Bahía Blanca, EdiUns, 2007.

Marcovecchio, J.; Andrade, S.; Ferrer, L.; Asteasuain, R.; De Marco, S.; Gavio, M., Scarlato, N.; Freije, R. \& Pucci, A. Mercury distribution in estuarine environments from Argentina: The detoxification and recovery of salt marshes after 15 years. Wetlands Ecol. Management, 9(4):317-22, 2001.

Massa, A. \& Lasta, C. Gatuzo "Mustelus schmitti”. In: Bezzi, S.; Akselman, R. \& Boschi, E. (eds). Síntesis del estado actual de las pesquerías marítimas argentinas y de la Cuenca del Plata. Años 1997-1998, con actualización de 1999. INIDEP, SAGPyA, Contrib., 1129:131-7, 2000. 
GALÍNDEZ, E. J.; DÍAZ ANDRADE, M. C.; MOYA, A. C. \& ESTECONDO, S. Morphological changes in the pregnant uterus of the smooth hound dogfish Mustelus schmitti springer, 1939 (Gatuzo) (Condrichthyes, Triakidae). Microscopic study and phylogenetic reproductive implications. Int. J. Morphol., 28(4):1003-1010, 2010.

McMillan, D. Fish histology. Female reproductive system. The Netherlands, Springer, 2007.

Menni, C. Distribución y biología de Squalus acanthias, Mustelus schmitti y Galeorhinus vitaminicus en el mar argentino en agosto-setiembre de 1978 (Chondrichthyes). Revta. Mus. La Plata (NS) (Zool.), 13(138):151-82, 1985.

Miranda, L. \& Vooren, C. Captura e esforço da pesca de elasmobrânquios demersais no Sul do Brasil nos anos de 1975 a 1997. Frente Marítimo, 19(B):217-31, 2003.

Musick, J. \& Ellis, J. Reproductive evolution of chondrychthyans. In: Hamlett, W. C. (ed). Reproductive Biology and Phylogeny of Chondrichthyes: Sharks, rays and chimaeras. Enfield, Science Publishers, 2005. pp.4571

Oddone, M.; Paesch. L. \& Norbis, W. Reproductive biology and seasonal distribution of Mustelus schmitti (Elasmobranchii: Triakidae) in the Rio de la Plata oceanic front, South-Western Atlantic. J. Mar. Biol. Ass. U.K., 85(5):1193-8, 2005.

Oddone, M.; Paesch, L.; Norbis, W. \& Velasco, G. Population structure, distribution and abundance patterns of the Patagonian smoothhound Mustelus schmitti Springer, 1939 (Chondrichthyes, Elasmobranchii, Triakidae) in the Rio de La Plata and inner continental shelf, SW Atlantic Ocean (3430'-39³0'S). Braz. J. Oceanograph., 55(3):167-77, 2007

Otake, T. \& Mizue, K. The fine structure of the placenta of the blue shark Prionace glauca. Jap. J. Ichthyol., 32(1):52-9, 1985.

Otake, T. \& Mizue, K. The fine structure of the intra-uterine epithelium during late gestation in the blue shark Prionace glauca. Jap. J. Ichthyol., 33(2):162-7, 1986.

Pereyra, I.; Orlando, L.; Norbis, W. \& Paesch, L. Variación espacial y temporal de la composición por tallas y sexos del gatuso Mustelus schmitti Springer, 1939 capturado por la pesca de arrastre en la costa oceánica uruguaya durante 2004. Rev. Biol. Mar. Oceanog., 43(1):159-66, 2008 .

Sidders, M.; Tamini, L.; Pérez, J. \& Chiaramonte, G. Biología reproductiva del gatuzo Mustelus schmitti Springer, 1939 (Chondrichthyes, Triakidae) en el área de Puerto Quequén, Provincia de Buenos Aires. Rev. Mus. Argentino Cienc. Nat., 7(1):89-101, 2005.
Soto, J. Distribution and reproductive biology of the striped smooth-hound Mustelus fasciatus (Garman, 1913)(Carcharhiniformes, Triakidae). Mare Magnum, 1(2):129-34, 2001.

Stehmann, M. Proposal of maturity stages scale for oviparous and viviparous cartilaginous fishes (Pisces, Chondrichthyes). Arch. Fishery Mar. Res., 50(1):23-48, 2002.

Storrie, M.; Walker, T.; Laurenson, L. \& Hamlett, W. Gestational morphogenesis of the uterine epithelium of the gummy shark (Mustelus antarcticus). J. Morphol., 270(3):319-36, 2009.

Van der Molen, S. \& Caille, G. Bahía Engaño: A north Patagonian nursery area for the smoothhound shark Mustelus schmitti (Carcharhiniformes, Triakidae). J. Mar. Biol. Ass. U.K., 81(5):851-5, 2001.

Vooren, C. Reproductive strategies of 8 species of viviparous elasmobranchs from Southern Brazil. Bull. Soc. Zool. France-Evol. Zool., 117(3):303-12, 1992.

Vooren, C. \& Klippel, S. Biologia e status de conservação do cação-listrado Mustelus fasciatus. In: Vooren, C. \& Klippel, S. (eds), Ações para a conservação de tubarões e raias no sul do Brasil. Porto Alegre, Igaré, 2005.

Walker, T. Spatial and temporal variation in the reproductive biology of gummy shark Mustelus antarcticus (Chondrichthyes: Triakidae) harvested off Southern Australia. Mar. Freshwater Res., 58(1):67-97, 2007.

Wourms, J. Viviparity: The maternal-fetal relationship in fishes. Am. Zool., 21:473-515, 1981.

Correspondence to:

Galíndez, E. J.

Lab. Histología Animal

Departamento de Biología, Bioquímica y Farmacia

UNS, San Juan 670, 8000

Bahía Blanca, Argentina

Email: galindez@criba.edu.ar

Received: 06-07-2010

Accepted: 11-09-2010 